\title{
A New Pathogenesis of Albuminuria: Role of Transcytosis
}

\author{
Fang-Fang He $\mathrm{Hi}^{\mathrm{a}}$ Gong ${ }^{\mathrm{a}}$ Zhen-Qiong Lia Liang Wu ${ }^{\mathrm{a}}$ Hua-Jun Jiang ${ }^{\mathrm{a}}$ \\ Hua Su ${ }^{a}$ Chun Zhang ${ }^{\mathrm{a}}$ Yu-Mei Wang ${ }^{\mathrm{a}}$ \\ aDepartment of Nephrology, Union Hospital, Tongji Medical College, Huazhong University of Science \\ and Technology, Wuhan, China
}

\section{Key Words}

Transcytosis • Albuminuria • Glomerular filtration barrier • Proximal tubular cell

\begin{abstract}
Transcytosis is an important intracellular transport process by which multicellular organisms selectively move cargoes from apical to basolateral membranes without disrupting cellular homeostasis. In kidney, macromolecular components in the serum, such as albumin, lowdensity lipoprotein and immunoglobulins, pass through the glomerular filtration barrier (GFB) and proximal tubular cells (PTCs) by transcytosis. Protein transcytosis plays a vital role in the pathology of albuminuria, which causes progressive destruction of the GFB structure and function. However, the pathophysiological consequences of protein transcytosis in the kidney remain largely unknown. This article summarizes recent researches on the regulation of albumin transcytosis across the GFB and PTCs in both physiological and pathological conditions. Understanding the mechanism of albumin transcytosis may reveal potential therapeutic targets for prevention or alleviation of the pathological consequences of albuminuria.
\end{abstract}

\section{Introduction}

(C) 2018 The Author(s)

Published by S. Karger AG, Basel

Transcytosis was firstly described in capillary permeability by Palade in the 1950s [1]. Subsequently, in 1979, Simionescu et al. [2] used the term "transcytosis" to describe the vectorial transport of macromolecules within plasmalemmal vesicles across capillary endothelial cells. Transcytosis is most commonly observed in epithelial cells [3-6], but also occurs in other cell types, including neurons [7], osteoclasts [8], intestinal membraneous (M) cells [9] and endothelial cells of capillaries or arteries. Cargoes reported to be transcytosed including albumin [10], immunoglobulin (Ig)A [11], low-density lipoprotein (LDL) [12], IgG $[4,13,14]$, insulin [15], transferrin [16, 17], and tumor necrosis factor (TNF)- $\alpha[18,19]$. These macromolecular proteins can be endocytosed, trafficked across the cell (intracellular trafficking), and finally exocytosed intactly by plasmalemmal vesicles (caveolae), without

F.-F. He, Y. Gong and Z.-Q. Li contributed equally to this work. 
entering the cellular cytoplasm. In different types of cells, protein transcytosis can be mediated by different receptors. For instance, albumin transport is mainly mediated by caveolae in endothelial cells [20-22], but in epithelial cells such as proximal tubular cells, it is mainly mediated by clathrin [21].

A crucial function of the transcytotic pathway is to regulate delivery of different proteins to maintain balanced tissue oncotic pressure and facilitate host-defense [23]. In addition, transcytosis is involved in the pathogenesis of a variety of diseases through different transcellular mechanisms. Previous studies reported that increased LDL transcytosis across arterial endothelial cells mediated by the LDL receptor-1 (Lox-1) promoted early atherosclerosis [24-26]. Recently, Buggia et al. [27] reported that abnormalities of $\beta$-site converting enzyme 1 (BACE1) transcytosis were involved in the pathogenesis of Alzheimer's disease (AD) and other neurodegenerative diseases. Transcytosis is also implicated in other pathological conditions such as stroke [18], cancer [28], inflammation [29], immunodeficiency [30] and kidney disease [31].

Recent studies have implicated that abnormal albumin transcytosis preceded kidney structural impairment in the early proteinuric renal diseases. Pascariu M et al. [32] reviewed the formation of nephrotic proteinuria during early stage of diabetes due to capillary hyperpermeability to plasma macromolecules. This process could be explained by intensification of transendothelial vesicular transport, rather than destabilization of the interendothelia junction. In this review, we summarize recent researches on albumin transcytosis across the glomerular filtration barrier (GFB) and proximal tubular cells (PTCs) in both physiological and pathological conditions, focusing on several regulatory factors and signaling pathways.

\section{The role of transcytosis in albuminuria}

Albuminuria is not only a hallmark of kidney damage, but also a factor contributing to the development and progression of glomerulosclerosis and tubulointerstitial fibrosis, which impairs kidney function [33]. In recent decades, numerous studies have explored the pathogenesis of albuminuria. The traditional view considered albuminuria to be largely caused by loss of the integrity of the GFB and defective reabsorption in the proximal tubule.

Three adjacent physiological layers that comprise the GFB, termed the fenestrated endothelium, glomerular basement membrane (GBM), and podocytes, sequentially aligned from the luminal aspect to the urinary space. Glomerular endothelia cells (GECs) with negatively charged glycocalyx covered on the luminal surface, GBM comprised with highly ordered extracellular matrix, podocytes with their interdigitating foot processes and the slit diaphragms that span the gaps between them, all of which form a size- and charge-selective filtration barrier. Under physiological conditions, only micromolecules and some small solutes such as water, ions and glucose can cross the GFB, but macromolecules are restricted. Under special pathological conditions or genetic defects, the integrity of the GFB is damaged, and then leads to increased permeability to macromolecules and resultant albuminuria. However, recent data has revealed that transcellular transport of plasma albumin across GECs and podocytes may constitute a new glomerular albumin filtration pathway [34-36]. Furthermore, insufficient transcytosis by dysfunctional PTCs also contributes to albuminuria. Under physiological conditions PTCs can reabsorb, transcytose

Table 1. Proteins transcytosis by glomerular endothelial cells (GECs), podocytes and proximal tubular cells (PTCs)

\begin{tabular}{lcc}
\hline Cell types & Basic roles & Ref \\
\hline GECs & $\begin{array}{c}\text { Receptor-mediated albumin transcytosis in GECs has been proven to } \\
\text { be involved in the formation of albuminuria }\end{array}$ & {$[34]$} \\
& & \\
Podocytes & Podocytes have the ability of albumin endocytosis and transcytosis & {$[35,36,44,45$,} \\
PTCs & Defects of rat PTCs in endocytosis and transcytosis are involved in the & pathogenesis of albuminuria \\
& & {$[37,46,57]$} \\
\hline
\end{tabular}




\section{Cellular Physiology Cell Physiol Biochem 2018;47:1274-1286

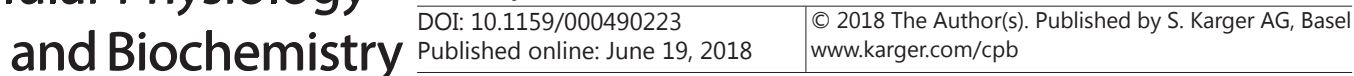 \\ He et al.: Role of Transcytosis in Albuminuria}

and process filtered albumin. Albumin is internalized to PTCs via megalin-cubilin-mediated, clathrin-dependent endocytosis. Defects in PTCs such as loss of megalin and cubilin result in albuminuria and proteinuria [37]. Both glomerular permeability and PTCs play fundamental, physiologic, synergistic, interactive and dynamic roles in the renal handling of albumin (Table 1).

\section{Transcytosis by GECS}

As the first line of the GFB, GECs play a crucial role in albumin filtration [38, 39]. GECs are a special endothelial phenotype with fenestrated transcellular pores, which are covered by abundant negatively charged glycocalyx. Since albumin is negatively charged, it can be restricted by GECs. A previous study demonstrated that albumin trafficked across the endothelial barrier through a caveolae-mediated transcytosis pathway [34]. Recent evidence indicates that glomerular charge and size selectivity is not impaired during the early phase of diabetic nephropathy [40-42], and albumin transendothelia transport may be responsible for the formation of albuminuria at the early stage of diabetic nephropathy. Thus, the conventional theory of "impairment of the size- and/or charge-selective filtration barrier" is insufficient to explain the pathogenesis of albuminuria during early stage diabetic nephropathy. This viewpoint provides innovative insight into the formation of albuminuria.

The transcellular transport of macromolecules is involved in many physiological processes, including protein catabolism and drug delivery. Receptor-mediated albumin transcytosis in GECs has been reported to be involved in the formation of albuminuria in a murine model of early stage diabetic nephropathy [34]. However, the precise mechanism by which pathological transcytosis in GECs underlies albuminuria remains unknown.

\section{Transcytosis by podocytes}

Glomerular podocytes, highly specialized epithelial cells, play an important role in glomerular permeability. Podocytes and slit diaphragms between their foot processes have the function to clear filtered proteins. Without clearance by podocytes, a significant amount of albumin and IgG would be trapped at the subpodocyte space. In pathologic conditions, a large amount of proteins accumulate under the foot processes of the podocyte [43]. Thus, it seems that podocytes may play a crucial role in cleaning the glomerular filter.

Increasing evidence has shown that podocytes are able to endocytose and transcytose proteins [35, 36, 44, 45]. Previous studies showed that cultured podocytes internalized albumin via transcytosis [36, 46-48]. Human, rat and murine experiments indicate that plasma proteins, such as ferritin, albumin and IgG, are found in the vacuoles of podocytes [4953]. Kinugase et al. [51] found that endocytosis of albumin in podocyte vesicles and on the apical membrane enhanced in a puromycin-induced proteinuric rat model, which mimicked minimal change nephritic lesions. In addition, they also used real-time confocal microscopy to record a delayed appearance of Evans Blue (EB)-labeled human albumin in the tubular lumen after injection, suggesting transcellular transport. On the contrary, after blocking transcytosis, albuminuria was decreased obviously. Another study revealed a tracer protein ferritin in podocyte lysosomes, suggesting an endocytic uptake of ferritin by podocytes from the GBM [52].

Podocytes are thought to clear proteins such as albumin and immunoglobulins accumulated at the GFB via the transport receptor neonatal Fc receptor (FcRn) [50]. In the kidneys, FcRn is expressed on podocytes and the brush border of the proximal tubular epithelium. FcRn mediates albumin transport in podocytes and preserves its function and lifespan [37]. Prominent, extensive protein vacuolation has been found in the podocytes of patients with heavy proteinuria [54]. In the early stage of diabetic nephropathy, podocytes exhibit enhanced endocytosis and degradation of IgG without increased urinary protein excretion [53].

By using intravital imaging, Schiessl et al. [35] first reported that in healthy young Munich Wistar Froemter (MWF) rats, acute angiotensin (Ang) II infusion promoted accumulation of albumin in the subpodocyte space, and enhanced endocytosis and transcytosis of plasma 
albumin by podocytes in a dose-dependent manner. Multi-photon microscopy showed that $86 \%$ of the endocytosed albumin was transported via transcytosis to the urinary space. This Ang II-induced albumin endocytosis by podocytes was megalin-dependent. Although structural impairment of podocytes is absent at the time of acute Ang II injection in heathy rats, increased albumin uptake by podocytes induces a proinflammatory response, which may cause podocyte injury in the long run [55]. Thus, release of endocytosed albumin by podocytes may be an early sign predicting subsequent podocyte injury [52]. In another experimental study, caveolae-dependent endocytosis of albumin was observed in cultured immortalized human podocytes [36]. In addition, albumin-containing vesicles were detected by electron microscopy in mouse, rat and human glomerular podocytes [56].

Taken together, podocyte clearance works to prevent glomerular diseases. The transcellular transport of proteins by endocytosis and transcytosis in the podocyte forms a new pathway of glomerular protein filtration, which differs from the classic pathway of paracellular transport through the slit diaphragm. Therefore, abnormal endocytic activity of podocytes under pathological conditions may be involved in nephritic albuminuria and long-term deterioration of podocyte function.

Transcytosis by PTCs

Transcytosis by PTCs is considered important under both physiologic and pathologic conditions. Transcytosis moves albumin across the PTCs from the apical to basolateral membrane, and into the extracellular fluid (reclamation pathway). This transport process is mediated by FcRn [57], which may work in concert with the megalin-cubilin complex located at the brush-border. PTCs take up albumin through receptor-mediated, clathrindependent and fluid-phase endocytosis. This process begins when an endocytic receptor (e.g. megalin-cubilin complex) binds albumin in the clathrin-coated pits. Then the $\mathrm{pH}$ of fluidphase endocytosis vesicles reduces in the endosome to approximately 5.0, causing handoff of albumin to the FcRn receptor. The FcRn pathway facilitates reabsorption and protects proteins from degradation, and mediates transcytosis in endosomal compartments. Some endocytosed proteins are catabolized into amino acids through the lysosomal degradation pathway, whereas the majority are recycled through the FcRn-medicated transcytotic pathway $[37,58]$. Hypoalbuminaemia has been observed in FcRn-defective mice or humans $[59,60]$.

PTCs play an important role in urinary albumin reabsorption and transcytosis. This reclamation process can minimize urinary albumin loss. Filtrated albumin from the glomerular filtrate can be resorbed by the PTCs, particularly in the S1 segment [37]. Selective PTC defects may disturb glomerular filtration and protein absorption in PTCs, thereby leading to nephrotic proteinuria or albuminuria [37]. Tojo et al. [46] reported that lipid peroxidation production was increased in the proximal tubules of diabetic rats. Albuminuria in early diabetic rats may be partially attributed to a decrease in albumin endocytosis, accompanied by reduced megalin expression and increased lipid peroxidation in PTCs. Taken together, defects of PTCs in endocytosis and transcytosis are involved in the pathogenesis of albuminuria.

\section{Regulatory factors and signaling pathways involved in albumin transcytosis}

The regulatory mechanisms underlying albumin transcytosis are only partially understood. Several regulatory factors involved in albumin transcytosis, such as Ang II, vascular endothelial growth factor (VEGF), C-reactive protein (CRP) are attracting attention (Table 2), and relevant signaling pathways, including caveolin-1 (Cav-1), mitochondrial reactive oxygen species (ROS)/Src, AMPK/cav-1, NF- $\kappa B / c a v-1$ pathway are under investigation (Fig. 1). Understanding the mechanism of albumin transcytosis may highlight therapeutic targets for the prevention or retard pathological albuminuria.

\section{KARGER}


Table 2. Summary of regulatory factors for proteins transcytosis. GECs, glomerular endothelial cells; ECs, endothelial cells; LDL, low density lipoprotein; VEGF, vascular endothelial growth factor; GFB, glomerular filtration barrier; CRP, C-react protein; TNF- $\alpha$, tumor necrosis factor- $\alpha$; ESL, endothelia surface layer

\begin{tabular}{|c|c|c|c|}
\hline Factors & Basic roles & Role during transcytosis & Ref \\
\hline Ang II & $\begin{array}{l}\text { One of the strongest vasoconstrictor substance; } \\
\text { Regulates blood pressure and protects renal function by binding } \\
\text { with its receptor }\end{array}$ & $\begin{array}{l}\text { Ang II enhances the endocytosis and transcytosis of plasma albumin } \\
\text { by podocytes, and increases LDL transcytosis across ECs }\end{array}$ & $\begin{array}{l}{[35,} \\
61]\end{array}$ \\
\hline VEGF & $\begin{array}{l}\text { Mediators of podocyte and GECs; } \\
\text { Regulates development and function of the GFB in the kidney; } \\
\text { Regulates endothelial cell migration, proliferation and } \\
\text { differentiation. }\end{array}$ & $\begin{array}{l}\text { Upregulated VEGF could increase the expression of Cav- } 1 \text { and } \\
\text { impact the transport of large molecules across endothelium }\end{array}$ & $\begin{array}{l}{[67} \\
68, \\
69, \\
70]\end{array}$ \\
\hline CRP & $\begin{array}{l}\text { An acute phase protein; } \\
\text { Stimulates ROS production, activates NF- } \kappa \text { B signaling }\end{array}$ & $\begin{array}{l}\text { CRP stimulates retention of LDL in human umbilical venous walls, } \\
\text { increases PKC and Src kinase activity, and promotes transcytosis of } \\
\text { LDL. }\end{array}$ & $\begin{array}{l}{[25,} \\
73, \\
74]\end{array}$ \\
\hline TNF- $\alpha$ & $\begin{array}{l}\text { Induces changes in glomerular endothelial fenestrate and ESL } \\
\text { during severe experimental endotoxemia through TNFR1 } \\
\text { signaling. }\end{array}$ & $\begin{array}{l}\text { TNF- } \alpha \text { promotes early athrosclerosis by increasing transcytosis of } \\
\text { LDL across endothelial cells. }\end{array}$ & {$[24]$} \\
\hline
\end{tabular}

Fig. 1. The relevant ROS/Cav-1 signaling pathways involved in albumin transcytosis in endothelial cells. TNF- $\alpha$, tumor necrosis factor- $\alpha$; VEGF-A, vascular endothelial growth factor A; LPS, lipopolysaccharide; VEGFR2, vascular endothelial growth factor receptor2; Cav-1, caveolin-1; p-Cav-1, phosphorylated caveolin-1; ROS, reactive oxygen species.

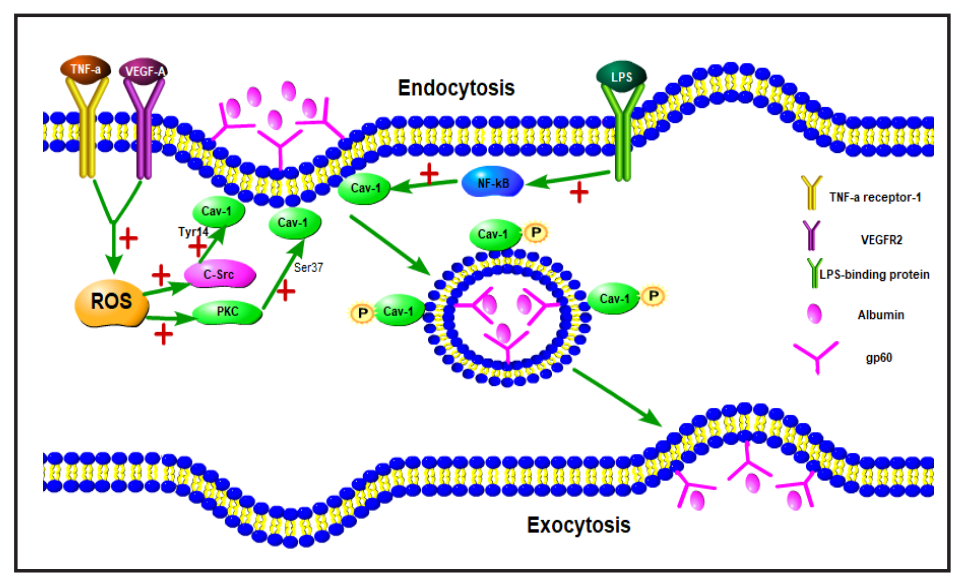

Ang II

Recently, Schiessl et al. [35] reported that Ang II infusion enhanced the endocytosis of albumin across rat podocytes. This process was mediated by the type 1 Ang II receptor (AT1 receptor) in a megalin-dependent manner, and was facilitated by increased albumin concentration in the subpodocyte space. Using an intravital multiphoton microscopy and electron microscopy, Schiessl et al. found that Ang II could acutely increase the filtration of albumin in the healthy kidney in a dose-dependent manner. The albumin-containing vesicles were colocalized with megalin in podocytes. These results revealed that acute Ang II infusion increased the concentration of albumin in the subpodocyte space, which could subsequently facilitate endocytosis of albumin by podocytes and finally lead to albuminuria. In contrast, gentamicin, a competitive inhibitor of megalin-dependent endocytosis, attenuated the uptake of albumin by podocytes. The majority of endocytosed albumin (86\%) was released into the urinary space via the transcellular pathway, and only $14 \%$ was acidified and degraded by lysosomes. Notably, no apoptosis or necrosis was observed during Ang II-induced albumin transcytosis in the healthy kidney.

The precise mechanism underlying Ang II-induced protein transcytosis in podocytes is largely unknown. In a previous study, Bian et al. [61] reported that Ang II upregulated intracellular ROS in endothelial cells. ROS could facilitate Ang II-induced transcytosis of LDL across endothelial cells, leading to the development of atherosclerosis. Ang II also remarkably increased the levels of LDL receptor, caveolin-1 and cavin-1. Given that podocytes can generate ROS in response to Ang II, the increased production of ROS may be one of the possible mechanisms. In addition, Ang II can induce VEGF synthesis in podocytes by activating the p38 MAP kinase pathway $[62,63]$. Thus, local changes in VEGF concentration are potentially associated with Ang II-induced protein transcytosis in podocytes [64]. 


\section{Cellular Physiology Cell Physiol Biochem 2018;47:1274-1286 \\ \begin{tabular}{c|c|c|} 
DOI: 10.1159/000490223 & O 2018 The Author(s). Published by S. Karger AG, Basel \\
www.karger.com/cpb
\end{tabular} \\ He et al.: Role of Transcytosis in Albuminuria}

Therefore, albumin transcytosis could be inhibited by blocking the Ang II/AT1 receptor pathway in the treatment of albuminuria.

\section{VEGF}

In the kidney, podocytes produce a variety of endothelial factors, including angiopoietin 1 and VEGF; whereas glomerular endothelial cells express their corresponding receptors Tie2 and VEGF receptor 2 in vivo [65]. VEGF widens endothelial cell-cell adhesive junctions and increases fenestrations of the cells. VEGF also induces formation of caveolae, enabling vesicle-based intracellular transport across the cytoplasm [66]. In 1999, Feng et al. [67] found that VEGF increased the permeability of retinal endothelial cells in a NOS-dependent transcytotic transport process mediated by caveolae. Recently, exposure to high glucose was reported to increase permeability of monolayer endothelial cells and up-regulate the expression of Cav-1, accompanied by the increased expression of VEGF [68]. Moreover, inhibition of the VEGF/kinase insert domain receptor (KDR) pathway using a selective inhibitor SU5416 could alleviate endothelial hyperpermeability and reverse the high glucose induced-expression of Cav-1. VEGF is a strong inducer of hyperpermeability in both physiological and pathological conditions [69]. It promotes the fission and fusion of caveolae, increases the caveolae number, and up-regulates Cav-1 expression [70]. As mentioned above, caveolae-mediated changes in permeability impact transport of large molecules across the endothelium [71]. Thus, VEGF-induced hyperpermeability may be implicated in albuminuria. However, the precise mechanism still needs further study.

\section{CRP}

CRP displays a pro-inflammatory phenotype, and it has been found to stimulate ROS production, activate NF- $\kappa \mathrm{B}$ signaling in endothelial cells, and up-regulate adhesion molecules and chemokines [72]. Bian et al. [25] found that CRP could directly enhance LDL transcytosis across endothelial cells and promote accumulation of LDL in the subendothelial space of the human umbilical vein wall, via stimulating ROS production and activating protein kinase $C$ (PKC) and Src kinase [73]. PKC phosphorylates Cav-1 at Ser [37], and Src phosphorylates Cav-1 at Tyr [14, 74]. CRP remarkably increases the expression of Cav-1 and cavin-1 (also known as polymerase I and transcript release factors/PTRF) in membrane raft domains when the caveolae/Cav-1/cavin-1 system participates in the transcellular transport of LDL [25]. These findings suggest that CRP plays an important role in PKC or Src kinase-stimulated transcytosis of LDL and the resultant development of early atherogenesis. We therefore infer the involvement of CRP in the albumin transcytosis across podocytes or endothelia cells through a similar mechanism. However, convincing evidence explaining the exact role of CRP in the formation of albuminuria via the albumin transcytosis is lacking.

\section{Cav-1}

Albumin internalization by endothelial cells is mediated by caveolae, small bulbshaped invaginations of the plasma membrane, of about 50-100 $\mathrm{nm}$ in diameter [20, 21, 75]. Caveolae are abundant in the endothelia, smooth muscle cells, and adipocytes. A variety of receptors, including LDL receptor, high-density lipoprotein receptor, albumin receptor, transferrin receptor, insulin receptor, and multiple channels and enzyme systems, are located in caveolae microdomains [22]. Cav-1 is a 20-22 kDa integral membrane protein enriched in caveolae [74, 76, 77]. In the kidney, Cav-1 is distinctly expressed on the renal cortex of mice and humans [34]. Cav-1 has been found to be significantly increased in the glomeruli of patients with primary and secondary glomerular diseases, such as IgA nephropathy, membranous nephropathy, crescent glomerulonephritis, minimal change disease and diabetic nephropathy [78]. Cav-1 is also associated with urinary albumin excretion [78, 79]. Caveolae-mediated transcytosis is the primary route of albumin trafficking across the intact endothelium [74, 80]. Albuminuria is not found in Cav1-knockout diabetic mice, and Cav-1 deficiency in vitro and in vivo protects against diabetic glomerulosclerosis, while intervention in the Cav-1/caveolae in kidneys prevents development of diabetic nephropathy 
Fig. 2. The signaling pathways involved in albumin transcytosis across glomerular endothelial cells in HG. HG, High glucose; AMPK, adenosine monophosphate activated protein kinase; Cav-1, caveolin-1; p-Cav-1, phosphorylated caveolin-1; ROS, reactive oxygen species.

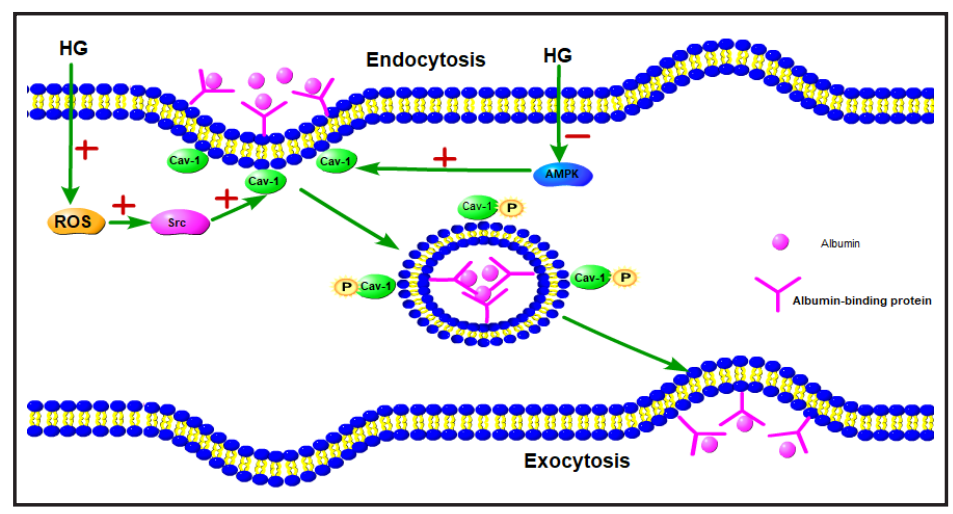

$[34,46,81]$. In vitro, the methyl beta cyclodextrin (M $3 C D$ ) disturbs caveolae trafficking and thus albumin endocytosis [34, 79]. These results reveal that in addition to the intercellular pathway, Cav-1 may play an important role in the pathogenesis of diabetic nephropathy by transcytosis in GECs (Fig. 2). In summary, transcytosis across GECs is a highly regulated, caveolae-dependent, selective process. Specific abnormalities in transcytosis processes may contribute to the genesis and development of albuminuria.

\section{Mitochondrial ROS signaling/Src}

ROS production promotes the phosphorylation of Cav-1 on Tyr ${ }^{14}$ during hyperosmotic shock and oxidative stress [82, 83]. The superoxide anion ROS is capable of enhancing endothelial permeability and activating Src kinase. Src family tyrosine kinases (SFKs) are nonreceptor cytoplasmic protein tyrosine kinases, which actively participate in the regulation of endothelial barrier function, for instance, interfering with hyperpermeability induced by proinflammatory mediators [84]. Low levels of basal SFK activity are required to maintain the integrity of the endothelial barrier in physiological states [84]. Nevertheless, the Src activity induced by a variety of inflammatory mediators can significantly increase endothelial permeability $[85,86]$. SFKs have also been reported to initiate and regulate transcellular transport by transcytosis [74], a process dependent on the modulation of caveolar dynamics. Src kinase is activated by phosphorylation at $\mathrm{Tyr}^{416}$ and/or dephosphorylation at $\mathrm{Tyr}^{527}$ [74]. Activated Src kinase can activate Cav-1 through direct phosphorylation or indirectly by inhibiting AMPK [34]. SFK signaling is required for activation of vesicle shuttling between apical and basal surfaces in transendothelial transport, increasing the numbers of assembled caveolae at the cell surface.

In a previous study, Coelho-Santos et al. [87] found that methylphenidate (MPH) promoted ROS production in human brain endothelial cells by activating Rac1-dependent NADPH oxidase (NOX) and c-Src at the plasma membrane. c-Src in return can phosphorylate Cav-1 on Tyr ${ }^{14}$, enhancing caveolae formation and transendothelial transport by transcytosis [88]. Therefore, methylphenidate increased the permeability of human brain endothelial cells via caveolae-dependent transcytosis, and Rac1/NOX-mediated ROS production is a key contributor to methylphenidate-induced vesicular transport. Similarly, diabetes is associated with significantly increased transcytosis of albumin in the heart, kidney and aorta [22]. High glucose levels enhance ROS production and activate Src kinase and Cav-1, thereby increase albumin transcytosis across GECs, and finally lead to albuminuria [34, 89]. Wu et al. [34] reported that high glucose increased albumin transcytosis in GECs via upregulation of the ROS/Src/Cav-1 pathway. Polyethylene glycol superoxide dismutase (PEG-SOD) or antioxidant $\mathrm{N}$-acetylcysteine (NAC), an ROS scavenger, reduced albumin transcytosis in GECs. These observations raise the possibility that the ROS/Src/cav-1 signaling pathway plays a crucial role in albumin trancytosis and albuminuria. 
AMPK/cav-1 pathway

AMPK is a negative regulator of Cav-1 [90]. Previous studies demonstrated that oxidative stress-induced Cav-1 phosphorylation and albumin endocytosis were inhibited by the activation of AMPK, via suppressing the dissociation of an upstream kinase of Cav-1, c-Abl, and its antioxidant enzyme, Prdx1 $[81,91]$. Moreover, inhibition of AMPK was found to activate Cav-1 indicating crosstalk between AMPK and the Src family kinase activity, whereby reduced Src kinase activity enhanced AMPK activity [34]. Wu et al. [34] reported that high glucose could downregulate the AMPK/Cav-1 pathway in GECs. Activation of AMPK by the activator 5-amino-4-imidazole carboxamide riboside (AICAR) could reduce glucose-stimulated albumin transcytosis. While knockdown of AMPK by siRNA in GECs led to an increased phosphorylation of Cav- 1 and enhanced albumin transcytosis. Thus, AMPK negatively regulates caveolea-mediated albumin transcytosis. These results reveal that AMPK plays an indispensable role in the albumin transport pathway, and inhibition of AMPK may be a potential cause of albuminuria.

\section{$N F-\kappa B / c a v-1$ pathway}

Activation of NF- $\kappa$ B has been reported to beassociated with elevated caveolin-1 expression and increased endothelial permeability induced by certain inflammatory mediators. Recently, Zhang et al. reported that the pro-inflammatory cytokine tumor necrosis factor- $\alpha$ (TNF- $\alpha$ ) increased LDL transcytosis across human umbilical vein endothelial cells, which promoted LDL accumulation in the vascular wall and resultant early atherosclerosis [24]. This study confirmed that TNF- $\alpha$ transcription factors, NF- $\kappa \mathrm{B}$ and peroxisome proliferator-activated receptor gamma (PPAR- $\gamma$ ) participated in the LDL intraendothelial transcytosis. Inhibition of NF- $\kappa B$ or PPAR- $\gamma$ could decrease over-expression of transcytosis-related proteins stimulated by TNF- $\alpha$, including LDL receptor and Cav-1, -2 , suggesting that inhibition of either NF- $\kappa$ B or PPAR $-\gamma$ substantially blocked the development of atherosclerosis. These findings provide a potential strategy for preventing and alleviating atherosclerosis.

The bacterial product lipopolysaccharide (LPS) is another important pro-inflammatory factor. LPS can increase Cav-1 expression and the number of caveolea in endothelial cells [92] and murine macrophages [93, 94], although the mechanism responsible remains unknown. In another study, the intronic region of Cav- 1 was found to contain NF- $\kappa B$ consensus sites, and LPS-mediated Cav-1 expression was NF- $\kappa B$ dependent, leading to increased caveolae number [95]. These findings partially explained the phenomenon of increased transendothelial albumin permeability induced by LPS in human lung microvascular endothelial cells. However, the extent to which these pro-inflammatory factors affect albumin transcytosis across GECs and podocytes has not been reported and deserves further attention.

\section{Conclusions}

Receptor-mediated transcytosis, a transportation of macromolecules between the apical and basolateral sides of various cell types, plays an essential role in the maintenance of cellular and body homeostasis. Albumin transcytosis across GECs, podocytes and PTCs has been implicated in chronic proteinuric nephropathy including diabetic nephropathy. The underlying etiology and pathogenesis of these diseases are complex and diverse, as manifested by the involvement of different regulators and signaling pathways in protein transcytosis under different circumstances. In order to further define and explore the role of protein trafficking in both physiological and pathological conditions, more profound studies will be needed to characterize the molecules and signaling pathways that regulate receptormediated endocytosis and transcytosis. Abnormalities in plasma protein transcytosis in GECs and podocytes may initiate deleterious inflammatory responses and cause deterioration of glomerular cell function. These changes in glomeruli increase the glomerular permeability of albumin. Inhibiting protein transcytosis across these cells may represent a novel therapeutic target for albuminuria and proteinuria. Future researches will be required to characterize the mechanisms underlying albumin transcytosis and outline therapeutic targets.

\section{KARGER}




\section{Cellular Physiology Cell Physiol Biochem 2018;47:1274-1286 \begin{tabular}{l|l} 
DOI: 10.1159/000490223 & $\begin{array}{l}\text { O 2018 The Author(s). Published by S. Karger AG, Basel } \\
\text { www.karger.com/cpb }\end{array}$ \\
\hline
\end{tabular}}

He et al.: Role of Transcytosis in Albuminuria

\section{Acknowledgements}

This work was supported by grants from the National Natural Science Foundation of China (No. 81570657, No. 81400720, No.30800523, No. 30900682, No. 81570671), a grant from Hubei Province Health and Family Planning Commission (No. WJ2015MB013),

\section{Disclosure Statement}

The authors have no conflicts of interest to declare.

\section{References}

1 Palade GE: The fine structure of blood capillaries. J Appl Physiol 1953; 24:1424.

-2 Simionescu N: Enzymatic tracers in the study of vascular permeability. J Histochem Cytochem 1979;27:1120-1130.

-3 He W, Ladinsky MS, Huey-Tubman KE, Jensen GJ, McIntosh JR, Bjorkman PJ: FcRn-mediated antibody transport across epithelial cells revealed by electron tomography. Nature 2008;455:542-546.

4 Mostov KE: Transepithelial transport of immunoglobulins. Annu Rev Immunol 1994;12:63-84.

5 Fung KYY, Fairn GD, Lee WL: Transcellular vesicular transport in epithelial and endothelial cells: Challenges and opportunities. Traffic 2018;19:5-18.

-6 Tenten V, Menzel S, Kunter U, Sicking EM, van Roeyen CR, Sanden SK, Kaldenbach M, Boor P, Fuss A, Uhlig S, Lanzmich R, Willemsen B, Dijkman H, Grepl M, Wild K, Kriz W, Smeets B, Floege J, Moeller MJ: Albumin is recycled from the primary urine by tubular transcytosis. J Am Soc Nephrol 2013;24:1966-1980.

7 Fabian RH: Retrograde axonal transport and transcytosis of immunoglobulins: implications for the pathogenesis of autoimmune motor neuron disease. Adv Neurol 1991;56:433-444.

-8 Salo J, Lehenkari P, Mulari M, Metsikko K, Vaananen HK: Removal of osteoclast bone resorption products by transcytosis. Science 1997;276:270-273.

-9 Landsverk T: The follicle-associated epithelium of the ileal Peyer's patch in ruminants is distinguished by its shedding of $50 \mathrm{~nm}$ particles. Immunol Cell Biol 1987;65:251-261.

10 Milici AJ, Watrous NE, Stukenbrok H, Palade GE: Transcytosis of albumin in capillary endothelium. J Cell Biol 1987; 105:2603-2612.

11 Perez JH, Branch WJ, Smith L, Mullock BM, Luzio JP: Investigation of endosomal compartments involved in endocytosis and transcytosis of polymeric immunoglobulin A by subcellular fractionation of perfused isolated rat liver. Biochem J 1988;251:763-770.

12 Vasile E, Simionescu M, Simionescu N: Visualization of the binding, endocytosis, and transcytosis of lowdensity lipoprotein in the arterial endothelium in situ. J Cell Biol 1983;96:1677-1689.

13 Patel HM, Wild AE: Fc receptor-mediated transcytosis of IgG-coated liposomes across epithelial barriers. FEBS Lett 1988;234:321-325.

-14 Hunziker W, Mellman I: Expression of macrophage-lymphocyte Fc receptors in Madin-Darby canine kidney cells: polarity and transcytosis differ for isoforms with or without coated pit localization domains. J Cell Biol 1989;109:3291-3302.

15 Duffy KR, Pardridge WM: Blood-brain barrier transcytosis of insulin in developing rabbits. Brain Res 1987;420:32-38.

16 Shah D, Shen WC: The establishment of polarity and enhanced transcytosis of transferrin receptors in enterocyte-like Caco-2 cells. J Drug Target 1994;2:93-99.

17 Pardridge WM, Eisenberg J, Yang J: Human blood-brain barrier transferrin receptor. Metabolism 1987;36:892-895.

18 Pan W, Kastin AJ: Tumor necrosis factor and stroke: role of the blood-brain barrier. Prog Neurobiol 2007;83:363-374.

19 Pan W, Kastin AJ, Daniel J, Yu C, Baryshnikova LM, von Bartheld CS: TNFalpha trafficking in cerebral vascular endothelial cells. J Neuroimmunol 2007;185:47-56. 


\section{Cellular Physiology Cell Physiol Biochem 2018;47:1274-1286 \begin{tabular}{l|l} 
DOI: 10.1159/000490223 & $\begin{array}{l}\text { O 2018 The Author(s). Published by S. Karger AG, Basel } \\
\text { www.karger.com/cpb }\end{array}$
\end{tabular}}

20 Mehta D, Malik AB: Signaling mechanisms regulating endothelial permeability. Physiol Rev 2006;86:279367.

21 Tuma P, Hubbard AL: Transcytosis: crossing cellular barriers. Physiol Rev 2003;83:871-932.

22 Simionescu M, Popov D, Sima A: Endothelial transcytosis in health and disease. Cell Tissue Res 2009;335:27-40.

23 Minshall RD, Malik AB: Transport across the endothelium: regulation of endothelial permeability. Handb Exp Pharmacol 2006;176:107-144.

24 Zhang Y, Yang X, Bian F, Wu P, Xing S, Xu G, Li W, Chi J, Ouyang C, Zheng T, Wu D, Zhang Y, Li Y, Jin S: TNFalpha promotes early atherosclerosis by increasing transcytosis of LDL across endothelial cells: crosstalk between NF-kappaB and PPAR-gamma. J Mol Cell Cardiol 2014;72:85-94.

25 Bian F, Yang X, Zhou F, Wu PH, Xing S, Xu G, Li W, Chi J, Ouyang C, Zhang Y, Xiong B, Li Y, Zheng T, Wu D, Chen $\mathrm{X}$, Jin S: C-reactive protein promotes atherosclerosis by increasing LDL transcytosis across endothelial cells. Br J Pharmacol 2014;171:2671-2684.

26 Li W, Yang X, Xing S, Bian F, Yao W, Bai X, Zheng T, Wu G, Jin S: Endogenous ceramide contributes to the transcytosis of oxLDL across endothelial cells and promotes its subendothelial retention in vascular wall. Oxid Med Cell Longev 2014;2014:823071.

27 Buggia-Prevot V, Thinakaran G: Significance of transcytosis in Alzheimer's disease: BACE1 takes the scenic route to axons. Bioessays 2015;37:888-898.

28 Smith JR, Braziel RM, Paoletti S, Lipp M, Uguccioni M, Rosenbaum JT: Expression of B-cell-attracting chemokine 1 (CXCL13) by malignant lymphocytes and vascular endothelium in primary central nervous system lymphoma. Blood 2003;101:815-821.

29 Middleton J, Patterson AM, Gardner L, Schmutz C, Ashton BA: Leukocyte extravasation: chemokine transport and presentation by the endothelium. Blood 2002;100:3853-3860.

-30 Ko SY, Pegu A, Rudicell RS, Yang ZY, Joyce MG, Chen X, Wang K, Bao S, Kraemer TD, Rath T, Zeng M, Schmidt SD, Todd JP, Penzak SR, Saunders KO, Nason MC, Haase AT, Rao SS, Blumberg RS, Mascola JR, Nabel GJ: Enhanced neonatal Fc receptor function improves protection against primate SHIV infection. Nature 2014;514:642-645.

-31 Sigismund S, Confalonieri S, Ciliberto A, Polo S, Scita G, Di Fiore PP: Endocytosis and signaling: cell logistics shape the eukaryotic cell plan. Physiol Rev 2012;92:273-366.

32 Pascariu M, Bendayan M, Ghitescu L: Correlated endothelial caveolin overexpression and increased transcytosis in experimental diabetes. J Histochem Cytochem 2004;52:65-76.

33 Abbate M, Zoja C, Remuzzi G: How does proteinuria cause progressive renal damage? J Am Soc Nephrol 2006;17:2974-2984.

34 Wu D, Yang X, Zheng T, Xing S, Wang J, Chi J, Bian F, Li W, Xu G, Bai X, Wu G, Jin S: A novel mechanism of action for salidroside to alleviate diabetic albuminuria: effects on albumin transcytosis across glomerular endothelial cells. Am J Physiol Endocrinol Metab 2016;310:E225-237.

-35 Schiessl IM, Hammer A, Kattler V, Gess B, Theilig F, Witzgall R, Castrop H: Intravital Imaging Reveals Angiotensin II-Induced Transcytosis of Albumin by Podocytes. J Am Soc Nephrol 2016;27:731-744.

-36 Dobrinskikh E, Okamura K, Kopp JB, Doctor RB, Blaine J: Human podocytes perform polarized, caveolaedependent albumin endocytosis. Am J Physiol Renal Physiol 2014;306:F941-951.

-37 Dickson LE, Wagner MC, Sandoval RM, Molitoris BA: The proximal tubule and albuminuria: really! J Am Soc Nephrol 2014;25:443-453.

38 Satchell S: The role of the glomerular endothelium in albumin handling. Nat Rev Nephrol 2013;9:717-725.

-39 Singh A, Satchell SC, Neal CR, McKenzie EA, Tooke JE, Mathieson PW: Glomerular endothelial glycocalyx constitutes a barrier to protein permeability. J Am Soc Nephrol 2007;18:2885-2893.

40 Rippe C, Rippe A, Torffvit 0, Rippe B: Size and charge selectivity of the glomerular filter in early experimental diabetes in rats. Am J Physiol Renal Physiol 2007;293:F1533-1538.

41 Holmquist P, Sjoblad S, Torffvit O: Pore size and charge selectivity of the glomerular membrane at the time of diagnosis of diabetes. Pediatr Nephrol 2004;19:1361-1366.

42 van den Born J, Pisa B, Bakker MA, Celie JW, Straatman C, Thomas S, Viberti GC, Kjellen L, Berden JH: No change in glomerular heparan sulfate structure in early human and experimental diabetic nephropathy. J Biol Chem 2006;281:29606-29613. 


\section{Cellular Physiology Cell Physiol Biochem 2018;47:1274-1286 \begin{tabular}{l|l} 
DOI: 10.1159/000490223 & $\begin{array}{l}\text { O 2018 The Author(s). Published by S. Karger AG, Basel } \\
\text { www.karger.com/cpb }\end{array}$
\end{tabular}}

He et al.: Role of Transcytosis in Albuminuria

-43 Adler S, Couser W: Immunologic mechanisms of renal disease. Am J Med Sci 1985;289:55-60.

44 Swiatecka-Urban A: Membrane trafficking in podocyte health and disease. Pediatr Nephrol 2013;28:17231737.

45 Castrop H, Schiessl IM: Novel routes of albumin passage across the glomerular filtration barrier. Acta Physiol (Oxf) 2017;219:544-553.

-46 Tojo A, Onozato ML, Ha H, Kurihara H, Sakai T, Goto A, Fujita T, Endou H: Reduced albumin reabsorption in the proximal tubule of early-stage diabetic rats. Histochem Cell Biol 2001;116:269-276.

-47 He F, Chen S, Wang H, Shao N, Tian X, Jiang H, Liu J, Zhu Z, Meng X, Zhang C: Regulation of CD2-associated protein influences podocyte endoplasmic reticulum stress-mediated apoptosis induced by albumin overload. Gene 2011;484:18-25.

48 Tojo A, Kinugasa S: Mechanisms of glomerular albumin filtration and tubular reabsorption. Int J Nephrol 2012;2012:481520.

-49 Wojtal KA, Hoekstra D, van Ijzendoorn SC: Anchoring of protein kinase A-regulatory subunit IIalpha to subapically positioned centrosomes mediates apical bile canalicular lumen development in response to oncostatin M but not cAMP. Mol Biol Cell 2007;18:2745-2754.

50 Akilesh S, Huber TB, Wu H, Wang G, Hartleben B, Kopp JB, Miner JH, Roopenian DC, Unanue ER, Shaw AS: Podocytes use FcRn to clear IgG from the glomerular basement membrane. Proc Natl Acad Sci U S A 2008;105:967-972.

51 Kinugasa S, Tojo A, Sakai T, Tsumura H, Takahashi M, Hirata Y, Fujita T: Selective albuminuria via podocyte albumin transport in puromycin nephrotic rats is attenuated by an inhibitor of NADPH oxidase. Kidney Int 2011;80:1328-1338.

-52 Farquhar MG, Wissig SL, Palade GE: Glomerular permeability I. Ferritin transfer across the normal glomerular capillary wall. 1961 J Am Soc Nephrol 1999;10:2645-2662.

-53 Ina K, Kitamura H, Tatsukawa S, Takayama T, Fujikura Y: Glomerular podocyte endocytosis of the diabetic rat. J Electron Microsc (Tokyo) 2002;51:275-279.

54 Yoshikawa N, Ito H, Akamatsu R, Hazikano H, Okada S, Matsuo T: Glomerular podocyte vacuolation in focal segmental glomerulosclerosis. Arch Pathol Lab Med 1986;110:394-398.

55 Okamura K, Dummer P, Kopp J, Qiu L, Levi M, Faubel S, Blaine J: Endocytosis of albumin by podocytes elicits an inflammatory response and induces apoptotic cell death. PLoS One 2013;8:e54817.

56 Eyre J, Ioannou K, Grubb BD, Saleem MA, Mathieson PW, Brunskill NJ, Christensen EI, Topham PS: Statinsensitive endocytosis of albumin by glomerular podocytes. Am J Physiol Renal Physiol 2007;292:F674-681.

57 Russo LM, Sandoval RM, McKee M, Osicka TM, Collins AB, Brown D, Molitoris BA, Comper WD: The normal kidney filters nephrotic levels of albumin retrieved by proximal tubule cells: retrieval is disrupted in nephrotic states. Kidney Int 2007;71:504-513.

58 Andersen JT, Daba MB, Berntzen G, Michaelsen TE, Sandlie I: Cross-species binding analyses of mouse and human neonatal Fc receptor show dramatic differences in immunoglobulin $\mathrm{G}$ and albumin binding. J Biol Chem 2010;285:4826-4836.

59 Sarav M, Wang Y, Hack BK, Chang A, Jensen M, Bao L, Quigg RJ: Renal FcRn reclaims albumin but facilitates elimination of IgG. J Am Soc Nephrol 2009;20:1941-1952.

-60 Wani MA, Haynes LD, Kim J, Bronson CL, Chaudhury C, Mohanty S, Waldmann TA, Robinson JM, Anderson CL: Familial hypercatabolic hypoproteinemia caused by deficiency of the neonatal Fc receptor, FcRn, due to a mutant beta2-microglobulin gene. Proc Natl Acad Sci U S A 2006;103:5084-5089.

61 Bian F, Cui J, Zheng T, Jin S: Reactive oxygen species mediate angiotensin II-induced transcytosis of lowdensity lipoprotein across endothelial cells. Int J Mol Med 2017;39:629-635.

62 Hsu HH, Hoffmann S, Endlich N, Velic A, Schwab A, Weide T, Schlatter E, Pavenstadt H: Mechanisms of angiotensin II signaling on cytoskeleton of podocytes. J Mol Med (Berl) 2008;86:1379-1394.

-63 Kang YS, Park YG, Kim BK, Han SY, Jee YH, Han KH, Lee MH, Song HK, Cha DR, Kang SW, Han DS: Angiotensin II stimulates the synthesis of vascular endothelial growth factor through the p38 mitogen activated protein kinase pathway in cultured mouse podocytes. J Mol Endocrinol 2006;36:377-388.

64 Eremina V, Jefferson JA, Kowalewska J, Hochster H, Haas M, Weisstuch J, Richardson C, Kopp JB, Kabir MG, Backx PH, Gerber HP, Ferrara N, Barisoni L, Alpers CE, Quaggin SE: VEGF inhibition and renal thrombotic microangiopathy. N Engl J Med 2008;358:1129-1136. 


\section{Cellular Physiology Cell Physiol Biochem 2018;47:1274-1286

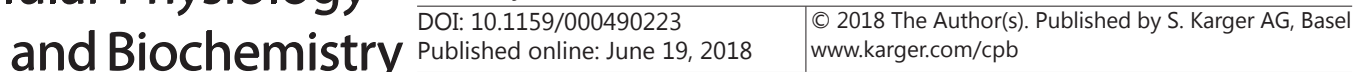

He et al.: Role of Transcytosis in Albuminuria

-65 Satchell SC, Anderson KL, Mathieson PW: Angiopoietin 1 and vascular endothelial growth factor modulate human glomerular endothelial cell barrier properties. J Am Soc Nephrol 2004;15:566-574.

66 Khoury CC, Ziyadeh FN: Angiogenic factors. Contrib Nephrol 2011;170:83-92.

67 Feng Y, Venema VJ, Venema RC, Tsai N, Behzadian MA, Caldwell RB: VEGF-induced permeability increase is mediated by caveolae. Invest Ophthalmol Vis Sci 1999;40:157-167.

-68 Tian C, Zhang R, Ye X, Zhang C, Jin X, Yamori Y, Hao L, Sun X, Ying C: Resveratrol ameliorates high-glucoseinduced hyperpermeability mediated by caveolae via VEGF/KDR pathway. Genes Nutr 2013;8:231-239.

69 Bates DO, Harper SJ: Regulation of vascular permeability by vascular endothelial growth factors. Vascul Pharmacol 2002;39:225-237.

-70 Chen J, Braet F, Brodsky S, Weinstein T, Romanov V, Noiri E, Goligorsky MS: VEGF-induced mobilization of caveolae and increase in permeability of endothelial cells. Am J Physiol Cell Physiol 2002;282:C1053-1063.

71 Komarova Y, Malik AB: Regulation of endothelial permeability via paracellular and transcellular transport pathways. Annu Rev Physiol 2010;72:463-493.

72 Zhong Y, Cheng CF, Luo YZ, Tian CW, Yang H, Liu BR, Chen MS, Chen YF, Liu SM: C-reactive protein stimulates RAGE expression in human coronary artery endothelial cells in vitro via ROS generation and ERK/NF-kappaB activation. Acta Pharmacol Sin 2015;36:440-447.

73 Alexander SP, Benson HE, Faccenda E, Pawson AJ, Sharman JL, Spedding M, Peters JA, Harmar AJ, Collaborators C: The Concise Guide to PHARMACOLOGY 2013/14: enzymes. Br J Pharmacol 2013;170:1797-1867.

74 Hu G, Minshall RD: Regulation of transendothelial permeability by Src kinase. Microvasc Res 2009;77:2125.

75 Anderson RG: Transendothelial movement and caveolae. Nat Biotechnol 2008;26:380-381.

76 Minshall RD, Tiruppathi C, Vogel SM, Malik AB: Vesicle formation and trafficking in endothelial cells and regulation of endothelial barrier function. Histochem Cell Biol 2002;117:105-112.

-77 Pelkmans L, Zerial M: Kinase-regulated quantal assemblies and kiss-and-run recycling of caveolae. Nature 2005;436:128-133.

78 Moriyama T, Tsuruta Y, Shimizu A, Itabashi M, Takei T, Horita S, Uchida K, Nitta K: The significance of caveolae in the glomeruli in glomerular disease. J Clin Pathol 2011;64:504-509.

79 Moriyama T, Sasaki K, Karasawa K, Uchida K, Nitta K: Intracellular transcytosis of albumin in glomerular endothelial cells after endocytosis through caveolae. J Cell Physiol 2017;232:3565-3573.

80 Predescu SA, Predescu DN, Malik AB: Molecular determinants of endothelial transcytosis and their role in endothelial permeability. Am J Physiol Lung Cell Mol Physiol 2007;293:L823-842.

-81 Takeuchi K, Morizane Y, Kamami-Levy C, Suzuki J, Kayama M, Cai W, Miller JW, Vavvas DG: AMP-dependent kinase inhibits oxidative stress-induced caveolin-1 phosphorylation and endocytosis by suppressing the dissociation between c-Abl and Prdx1 proteins in endothelial cells. J Biol Chem 2013;288:20581-20591.

82 Volonte D, Galbiati F, Pestell RG, Lisanti MP: Cellular stress induces the tyrosine phosphorylation of caveolin-1 (Tyr(14)) via activation of p38 mitogen-activated protein kinase and c-Src kinase. Evidence for caveolae, the actin cytoskeleton, and focal adhesions as mechanical sensors of osmotic stress. J Biol Chem 2001;276:8094-8103.

-83 Aoki T, Nomura R, Fujimoto T: Tyrosine phosphorylation of caveolin-1 in the endothelium. Exp Cell Res 1999;253:629-636.

84 Hu G, Place AT, Minshall RD: Regulation of endothelial permeability by Src kinase signaling: vascular leakage versus transcellular transport of drugs and macromolecules. Chem Biol Interact 2008;171:177189.

85 Kim D, Duran WN: Platelet-activating factor stimulates protein tyrosine kinase in hamster cheek pouch microcirculation. Am J Physiol 1995;268:H399-403.

86 van Nieuw Amerongen GP, van Delft S, Vermeer MA, Collard JG, van Hinsbergh VW: Activation of RhoA by thrombin in endothelial hyperpermeability: role of Rho kinase and protein tyrosine kinases. Circ Res 2000;87:335-340.

87 Coelho-Santos V, Socodato R, Portugal C, Leitao RA, Rito M, Barbosa M, Couraud PO, Romero IA, Weksler B, Minshall RD, Fontes-Ribeiro C, Summavielle T, Relvas JB, Silva AP: Methylphenidate-triggered ROS generation promotes caveolae-mediated transcytosis via Rac1 signaling and c-Src-dependent caveolin-1 phosphorylation in human brain endothelial cells. Cell Mol Life Sci 2016;73:4701-4716. 


\section{Cellular Physiology Cell Physiol Biochem 2018;47:1274-1286 \begin{tabular}{l|l} 
DOI: 10.1159/000490223 & $\begin{array}{l}\text { O } 2018 \text { The Author(s). Published by S. Karger AG, Basel } \\
\text { www.karger.com/cpb }\end{array}$ \\
\hline
\end{tabular}}

He et al.: Role of Transcytosis in Albuminuria

-88 Lee H, Volonte D, Galbiati F, Iyengar P, Lublin DM, Bregman DB, Wilson MT, Campos-Gonzalez R, Bouzahzah B, Pestell RG, Scherer PE, Lisanti MP: Constitutive and growth factor-regulated phosphorylation of caveolin-1 occurs at the same site (Tyr-14) in vivo: identification of a c-Src/Cav-1/Grb7 signaling cassette. Mol Endocrinol 2000;14:1750-1775.

89 Taniguchi K, Xia L, Goldberg HJ, Lee KW, Shah A, Stavar L, Masson EA, Momen A, Shikatani EA, John R, Husain M, Fantus IG: Inhibition of Src kinase blocks high glucose-induced EGFR transactivation and collagen synthesis in mesangial cells and prevents diabetic nephropathy in mice. Diabetes 2013;62:38743886.

-90 Levine YC, Li GK, Michel T: Agonist-modulated regulation of AMP-activated protein kinase (AMPK) in endothelial cells. Evidence for an AMPK -> Rac1 -> Akt -> endothelial nitric-oxide synthase pathway. J Biol Chem 2007;282:20351-20364.

-91 Zhang W, Wang Q, Wu Y, Moriasi C, Liu Z, Dai X, Wang Q Liu W, Yuan ZY, Zou MH: Endothelial cell-specific liver kinase B1 deletion causes endothelial dysfunction and hypertension in mice in vivo. Circulation 2014;129:1428-1439.

$\$ 92$ Zhao B, Bowden RA, Stavchansky SA, Bowman PD: Human endothelial cell response to gram-negative lipopolysaccharide assessed with cDNA microarrays. Am J Physiol Cell Physiol 2001;281:C1587-1595.

-93 Lei MG, Morrison DC: Differential expression of caveolin-1 in lipopolysaccharide-activated murine macrophages. Infect Immun 2000;68:5084-5089.

$\$ 94$ Lei MG, Tan X, Qureshi N, Morrison DC: Regulation of cellular caveolin-1 protein expression in murine macrophages by microbial products. Infect Immun 2005;73:8136-8143.

95 Tiruppathi C, Shimizu J, Miyawaki-Shimizu K, Vogel SM, Bair AM, Minshall RD, Predescu D, Malik AB: Role of NF-kappaB-dependent caveolin-1 expression in the mechanism of increased endothelial permeability induced by lipopolysaccharide. J Biol Chem 2008;283:4210-4218. 